\title{
Archipel
}

ARCHIPEL Études interdisciplinaires sur le monde insulindien

99 | 2020

Varia

\section{A Daughter's Memory : 1965 in Animation}

\section{Grace Leksana}

\section{OpenEdition}

Journals

Electronic version

URL: http://journals.openedition.org/archipel/1667

DOI: 10.4000/archipel. 1667

ISSN: 2104-3655

\section{Publisher}

Association Archipel

\section{Printed version}

Date of publication: 15 July 2020

Number of pages: $41-45$

ISBN: 978-2-910513-83-2

ISSN: 0044-8613

\section{Electronic reference}

Grace Leksana, “A Daughter's Memory : 1965 in Animation”, Archipel [Online], 99 | 2020, Online since 02 June 2020, connection on 15 March 2021. URL: http://journals.openedition.org/archipel/1667 ; DOI: https://doi.org/10.4000/archipel.1667 
GRACE LEKSANA ${ }^{1}$

\section{A Daughter's Memory : 1965 in Animation}

A Daughter's Memory ${ }^{1}$

Animated short film in color, $8 \mathrm{~min} .40 \mathrm{sec}$., 2019

Director : Kartika Pratiwi

Production : Kotak Hitam Forum

Language : Indonesian with English subtitles

The animated short film starts with a Scrabble board game. One night in a house in Gunung Sahari, three siblings are playing Scrabble. These children compose words in Indonesian as they are trying to win the game. However, their situation transforms drastically when a military truck arrives at that house. Captain Suroso enters the house, takes over the Scrabble board, and writes the word "Njoto" - the name of one of the Indonesian Communist Party (PKI)'s central committee leaders, who was also a supervisor of the party's Harian Rakjat newspaper and a minister in the 1962 Cabinet. Njoto is also the father of those children.

Captain Suroso's hunt for Njoto was part of a national-scale military project to eliminate the Left in Indonesia in 1965 and 1966 (then again in 1968 in East Java). During that period, more than 500,000 people were killed, detained, tortured, and experienced acts of gross human rights violations. While this narrative of violence remains at the margins of Indonesia's historiography, the event that triggered it has been widely commemorated. This is the 30

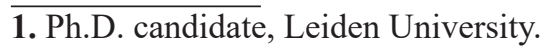


September Movement, or Gerakan 30 September 1965 (G30S), which is centered on the death of six generals and one army officer during an attempted military coup. The government accused the PKI of being the instigator, which became a pretext for a complete annihilation project against the communists, the Left, and their sympathizers.

A Daughter's Memory presents another face of this historical event. Using Scrabble as a gimmick, it connects national violence with a family's memory. By capturing the story of a young daughter who lost her father, the film aims to represent the 1965-1966 violence from an alternative perspective. It is a national tragedy but also a personal experience. It is not only about loss and sorrow but also about struggles and overcoming fear. These experiences presented in the film are the ones of Svetlana Dayani Njoto, one of Njoto's daughters who has been actively involved in the film project. Through Svetlana's narratives, Njoto, who is remembered in Indonesia's history as a PKI leader, became another figure - a patient father who taught his daughter how to use the typewriter, for example. But Svetlana's narrative does not spare the details of the horror that happened in 1965 and 1966. She recalls her experience of being detained in a jail along with her mother and other siblings. She remembers seeing victims of brutal interrogation techniques being dragged back to their cells covered in blood on a daily basis. Svetlana was often instructed to clean up the interrogation room in the morning when it was not in use. Here she saw traces of torture, such as the stingray tail and the floor covered with blood. ${ }^{2}$

The film reveals that Svetlana began to understand the larger picture when she was in middle school, particularly the reason for her father's disappearance and their family's detention. In her history textbook, she saw her father's picture along with other PKI leaders - Lukman and Aidit - with the caption "PKI's kingpin" or gembong PKI. They were blamed for the G30S movement and the deaths of the generals. Along with their families, they became enemies of the state. Svetlana and her family had to hide their identities until 1987, when she decided to start using her real name again. Through the story of the young Svetlana, A Daughter's Memory conveys a different narrative of 1965, one in stark contrast to the State's narrative that revolves mainly around the G30S and the deaths of the generals. More than that, this memory of a young daughter enables the audience to comprehend what 1965 violence actually represents for families and ordinary citizens - the losses and struggles that have left traces up to the present.

2. Svetlana's memory also appears in Soe Tjen Marching (ed.). The End of Silence: Accounts of the 1965 Genocide in Indonesia. Amsterdam : Amsterdam University Press, 2017. 


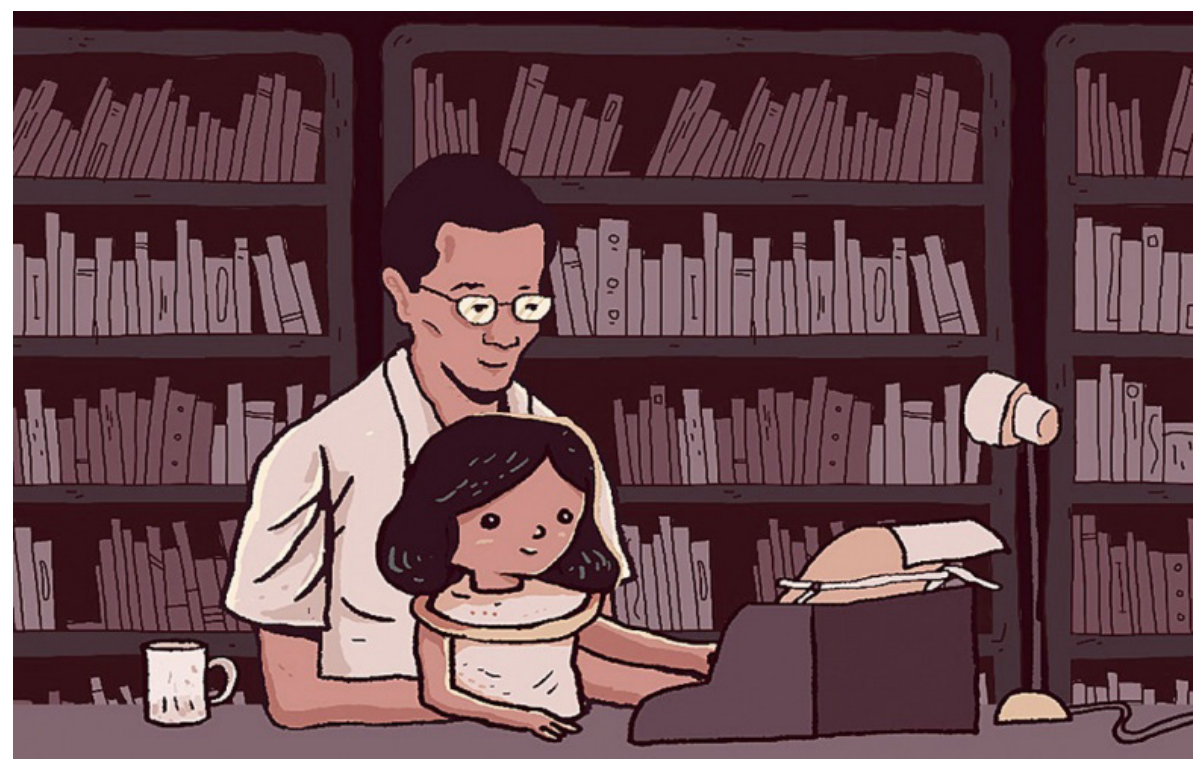

A Daughter's Memory

\section{Producing the Film}

The most interesting aspect of this film is that it is a short, animated documentary. Kartika Pratiwi is the director and producer. She is the founder, managing director, and one of the filmmakers at Kotak Hitam Forum, an organization that uses audio-visual works as a medium within Indonesia's cultural movement to highlight and discuss Indonesia's diversity. Besides producing films, Kotak Hitam Forum also conducts educational programs for the public in the form of discussions, workshops, and research. They believe that audio-visual media has the strength to convey and generate critical ideas and to provide spaces for marginalized voices.

With this background, presenting topics related to the violence in 1965 has been a passion for Kotak Hitam Forum's founders since its establishment in 2008. Related to this specific event in Indonesia's political history, Kotak Hitam has produced three other documentaries, including Yang Bertanah Air, Tak Bertanah (A Motherland but no land, 2008), r.i. (The republic of indonesia, 2010 ) and Api Kartini (Kartini's Fire, 2012). A Daughter's Memory was produced in 2019 and takes the form of an animated documentary. This genre was chosen because the director wanted to experiment. While several documentaries on the 1965-1966 violence have already been shown in previous years, the challenge was to produce another documentary, that would 
be interesting and, at the same time, convey a strong message through the personal figures of survivors such as Svetlana. As Kartika Pratiwi mentioned in an interview with The Jakarta Post (1 November 2019), she sees digital technology as something that could change the way memories and history are preserved. Her work, together with her production team, received acclaim when A Daughter's Memory was awarded the prize for Best Film and Best Animation at ReelOzInd! 2019, a short film festival in Australia dedicated to Indonesian and Australian productions.

Kartika Pertiwi wanted to use a narrative from second-generation victims for a particular reason. In a discussion with Watch 65 in Leiden, on 15 July 2019 , she explained that narrative is the only thing that these victims have to express themselves. Recording and presenting them visually is one way to create a different kind of archive - to preserve their memories - as they are also aging. This type of films creates spaces for victims to articulate their own memories about the violence. It should be participative and involving the victims who actually hold these memories. This is why, for the director, the memorialization of the 1965-1966 violence should find its own form and not merely reproduce successful forms of memorialization found in other countries with similar histories of mass violence.

\section{Future Directions}

While Indonesia is moving very slowly toward the memorialization of the 1965-1966 violence, at the grassroots level, we are seeing the increasing involvement of younger generations - as exemplified in the film - in creating and producing mediums to preserve the diverse narratives of violence. This tendency is what Marianne Hirsch, a leading scholar in memory studies, has named postmemory:

The relationship that the 'generation after' bears to the personal, collective, and cultural trauma of those who came before - to experiences they 'remember' only by means of the stories, images, and behaviors among which they grew up. But these experiences were transmitted to them so deeply and affectively as to seem to constitute memories in their own right. Postmemory's connection to the past is thus actually mediated not by recall but by imaginative investment, projection, and creation. (Hirsch 2012: 5)

Hirsch developed her concept while working with Holocaust survivors. The case of Indonesia in 1965 presents a different yet interesting aspect of postmemory. In the context of impunity and exclusion of violence against the Left in Indonesia's history, Indonesians have lived for years within the public discourse initiated by the State on G30S but also within the private narratives of the mass violence in 1965. Decades after the violence and after the fall of Suharto, these narratives are not exclusively competing but also coexisting. Svetlana's story shows how she managed to comprehend her family's experience when she encountered the State's narrative - the history textbook 
that wrongly depicted her father as a national traitor. Indonesia's postmemory of 1965, therefore, is built by understanding these diverse narratives rather than negating any of them. Both the killings of the generals in G30S and the mass killings occurred simultaneously in 1965 and should become part of Indonesia's history. The fabricated anti-communist narrative is also part of the process in understanding this violent past. One should be understood in relation to each other, not silenced for the benefit of the other.

Both the public and private narratives drove Indonesians to take action to expose more voices on the events surrounding the violence of 1965 and 1966. While victims themselves are becoming older and dying, it is now the younger generation who is taking the initiative. These people were not necessarily affected by the past violence like victims' families, but they are driven by curiosity and motives to reveal the 'truth.' This is a generation born and raised toward the end of the New Order in a more democratic atmosphere and, thus, tired of being force-fed with a monolithic version of history. As Kartika Pertiwi explained in the discussion with Watch 65, her motive to produce documentaries on the 1965 violence was partly because of her guilt, as she once believed the New Order's national narrative. Furthermore, this post-New Order generation is taking a more creative and digital approach to convey experiences of violence. Besides audio-visual formats such as those produced by Kotak Hitam Forum, there is also a digital media platform, such as Ingat 65, which has compiled testimonies from the younger generations related to 1965 . Others take creative performances as their medium, such as the Papermoon Puppet Theatre or the collaboration between the singing choir Dialita, which consists of women survivors and young generations of Indonesian musicians. There is no reason to believe that this tendency will change in the near future. Therefore, one can hope that the younger generations will remain increasingly involved in creative and innovative ways of talking about 1965.

\section{References}

Figge, Katrin. “A Daughter's Memory: A Voice for the Forgotten.” Jakarta Post, November 1, 2019.

Hirsch, Marianne. The Generation of Postmemory: Writing and Visual Culture After the Holocaust. New York : Columbia University Press, 2012. 
